\title{
ПОСТПОЗИТИВНИ ЧЛАН И ДЕМОНСТРАТИВНЕ ЗАМЕНИЦЕ У УРБАНОМ ПИРОТСКОМ ВАРИЈЕТЕТУ
}

\begin{abstract}
Рад се бави семантичко-прагматичким особинама постпозитивног одређеног члана и демонстративних заменица у урбаном пиротском варијетету. У дијалектолошкој литератури уобичајено се тврди да постпозитивна чланска морфема има демонстративну и чланску функцију (БЕЛИЋ 1905; СТАНОЈЕВИЋ 1911; БОГДАНОВИЋ 1979; ЋИРИЋ 1983), те да ,демонстративне нијансе живе у члану” (ВУКАДИНОВИЋ 1996: 203) без дубље анализе под којим условима се јављају демонстративна и дефинитна (одређена) интерпретација. Показаћемо да постоје контексти у којима је за изворне говорнике урбаног пиротског варијетета прагматички прихватљив искључиво члан или, пак, показна заменица. Наиме, резултати истраживања у којем су испитаници оцењивали прагматичку прихватљивост исказа у задатом контексту на тростепеној Ликертовој скали недвосмислено показују да се чланом маркирају старост у дискурсу референта релационих именица, те јединственост, асоцијативна анафора и генеричке именичке синтагме, док се демонстративне заменице редовно појављују приликом просторног упућивања у контрастивним, те емфатичким неепитетским контекстима.

Кључне речи: одређени члан, демонстративи, урбани пиротски варијетет, старост у дискурсу, јединственост, асоцијативна анафора, генеричке именичке синтагме, контрастивност, емфатичност.
\end{abstract}

\section{1. Увод. Предмет истраживања}

Једна од најспецифичнијих особина крајњих југоисточних говора Србије представља постпозитивни одређени члан. Његова употреба ограничена је на уски погранични појас тимочколужничког и заплањског ${ }^{3}$ варије-

\footnotetext{
${ }^{1}$ branimir.stankovic@filfak.ni.ac.rs

${ }^{2}$ Рад је настао у оквиру пројекта Српски језик некад и сад: лингвистичка истраживаға Филозофског факултета у Нишу (бр. 360/1-16-10-01).

${ }^{3}$ Постпозитивни члан у заплањском се врло ретко употребљава и иако се у дијалектолошкој
} 
тета ${ }^{4}$, при чему треба нагласити да није обавезујућа за говорнике, каква је ситуација у осталим идиомима тзв. Балканског језичког савеза (детаљније в. следеће поглавље рада). У домаћој дијалектолошкој литератури аутори су сагласни у оцени да постпозитивна чланска морфема има демонстративну и чланску функцију (БЕЛИЋ 1905; СТАНОЈЕВИЋ 1911; БОГДАНОВИЋ 1979; ЋИРИЋ 1983), те да „демонстративне нијансе живе у члану” (ВУКАДИНОВИЋ 1996: 203). У раду ћемо показати да ипак има контекста у којима је говорницима прихватљива искључиво једна или друга категорија. Наиме, на основу анализе транскрибоване грађе и резултата експерименталног истраживања прагматичке прихватљивости исказа у задатим окружењима, може се поуздано тврдити да говорници урбаног пиротског варијетета постпозитивни члан употребљавају да маркирају дискурсстаре референте релационих именица, јединственост денотата, генеричке именичке синтагме, те асоцијативну анафору, док се демонстративима служе да обележе контрастивност и експресивност у емфатичким контекстима.

Рад има следећу композицију. У другом поглављу представићемо кратку историју проучавања одређеног члана у балканистици. Треће поглавље посвећено је досадашњим истраживањима односа члана и демонстратива у домаћој дијалектолошкој литератури. Четврто поглавље доноси опис наше језичке и лингвистичке интуиције, те методологије примењене у истраживању. У централном, петом делу рада презентоваћемо резултате спроведеног корпусног и експерименталног истраживања, са детаљним освртом на шест типова контекста у којима изворни говорници бирају једну или другу категорију. Резимираћемо у шестом поглављу.

\section{2. Одређени члан у балканском контексту}

Одређени члан представља једну од првих примећених заједничких особина језика који припадају Балканском језичком савезу. Још Јернеј Копитар у пионирском раду „Albanische, walachische und bulgarische Sprache” из 1829. године констатује, између осталог, присуство одређеног члана позиционираног иза именице ${ }^{5}$ у албанском, влашком (румунском) и бугарском

литератури помињу и анализирају његове различите форме и евентуалне семантичке разлике (нпр. големијат:големити човек), у транскрибованој грађи веома га је тешко пронаћи, те је немогуће изводити прецизне закључке о семантичко-прагматичким условима под којима се јавља. Овакав је случај са корпусом презентованим у монографији „Говори Бучума и Белог Потока“ Недељка Богдановића (1979), у коме нема ниједног примера са одређеним чланом у грађи из Белог Потока (сврљишки), а забележена је само једна чланована именичка синтагма у материјалу из Бучума (тимочколужнички), телевизора (БОГДАНОВИЋ 1979: 169).

${ }^{4}$ У раду ћемо термином варијетет реферисати на било коју географски дистрибуирану варијацију језика без обзира на претпостављени ниво класификације.

${ }^{5}$ Ова констатација је тачна само у случају тзв. голих именица, јер се постпозитивни члан у 
језику (KOPITAR 1829). Више од три деценије касније, бавећи се словенским граматичким, фонолошким и лексичким елементима у румунском, Франц Миклошич се осврће и на одређене језичке појаве у румунском „које је могуће пратити до изворних древних времена" (MIKLOSICH 1861: 6). Један од побројаних феномена ${ }^{6}$ је и „нероманска позиција члана иза именице, непозната и словенским језицима" (ибид.), коју овај аутор констатује у бугарском, румунском и албанском. Притом се Миклошич позива на следеће Копитареве примере из румунског (1) и албанског (2), уз констатацију да је погрешно мишљење Тимотеја Ципаријуа (Timotei Cipariu) (1855) да су бугарски и албански језик члан преузели из румунског (TIMOTEI 1855):
(1) ale $^{7}$
ta-le
од $^{8}$
ваш-одР.чЛАН ${ }^{9}$
sunt (рум.)
cy
„Ваши су / Они су твоји.”
(2) jane të
të
су ОДР.ЧЛАН
tu-të (алб.)
твоји-ОДР.ЧЛАН

„Твоји су / Они су твоји.”

Почеци ареалне лингвистике и дефинисање разлике између појма језичка породица (Sprachfamilie) компаративноисторијске лингвистике и новог појма језички савез (Sprachbund) контактне лингвистике везују се за предлог број 16 Николаја Трубецкоја изнет на Првом међународном лингвистичком конгресу у Хагу 1928. године (TRUBETZKOY 1928: 17-18). У њему Трубецкој потоњи појам дефинише као групу језика које карактеришу велике сличности у синтакси и деривацији, са великим бројем заједничких лексема из области културе (Kulturwörter), али без заједничких основних лексема (Elementarwörter), а понекад и без сличности у фонолошком систему. Као пример за језички савез овај аутор наводи управо балканске језике, који се од тада у литератури називају „Balkan Sprachbund”, иако има лингвиста који термине балканизам и језички савез сматрају непримереним (в. нпр.

поменутим језицима јавља иза иницијалног члана именичке синтагме, осим у случајевима када се ради о одређеним класама квантификатора и демонстративних заменица.

${ }^{6}$ Осим одређеног члана, Миклошич помиње и грађење футура помоћу velle глагола (поред глагола бити (буде) и има(ти) у словенским језицима) и инфинитива, затим губљење инфинитива, исказивање генитива и датива истом падежном формом, учесталу употребу вокала $ә$, иницијално слоготворно $M$ и $t$ (у румунском и албанском), замену гласова $t$ и $p$, те $p$ и $л$, истовремену употребу акцентогених и енклитичких форми личне заменице, те формирање бројева између 11 и 19 помоћу бројева 1-9, одговарајућег предлога и броја 10 (MIKLOSICH 1861: 6-8).

\footnotetext{
${ }^{7}$ Сви наредни примери су адаптирани савременим правописним решењима у одговарајућим језицима.

${ }^{8}$ Глосе у Копитаревим примерима (представљеним у (1) и (2)) наше су.

${ }^{9}$ ОдР.члАН $=$ одређени члан
} 
WEINREICH 1953; 1958; REITER 1994; HINDRICHS 1999).

Истинским почетком систематског истраживања балканизама сматра се капитално дело „Linguistique balkanique. Problèmes et résultats” Крестијана Сендфилда (Kristian Sandfeld), објављено 1930. године. У њему дански лингвиста анализира стотинак тзв. општих слагања/поклапања (concordances générales) и слагања/поклапања међу појединим балканским језицима (concordances entre différentes langues Balkaniques), у које, поред (гегијског и тоскијског) албанског, (дако)румунског и бугарског, укључује и мегленоромански, арумунски, македонски (macédo-bulgar) и новогрчки, уз навођење многобројних примера и из српског, „српско-хрватског” и турског (SANDFELD 1930). Сендфилд износи и нову хипотезу о пореклу балканизама, по којој је грчки, као језик доминантне културе на овим просторима, утицао на све остале језике, што је историјски било „потпомогнуто” византијском, а касније и турском хегемонијом ${ }^{10}$. Први на списку побројаних балканизама је постпозитивни одређени члан - иако је новогрчки члан препозитиван и карактерише га и тзв. полидефинитност, односно, може се појавити испред више чланова именичке синтагме, што има својих синтаксичких и семантичких последица ${ }^{11}$ (в. више у LEKAKOU \& KARATSAREAS 2015):

(3) to megalo to petrino to spiti (грч.) одР.члАН велика одР.чЛАН камена одР.члАН кућа „велика камена кућа”

У потоњој балканистичкој литератури постулиран је већи број различитих класификација језика Балканског језичког савеза, уз различите оцене који језици га заиста чине, постоје ли централни и периферни, типични и мање типични, више и мање балканизовани језици итд. (BIRNBAUM 1965; 1983; SCHALLER 1975; SOLTA 1980; JOSEPH 1983; ACEHOBA 2002; SOBOLEV 2004). Различите су и оцене у погледу особина које можемо назвати балканским, али се на овом списку редовито налази и одређени члан, који је постпозитиван у свим балканским језицима сем грчког и балканског ромског, који такође „показује много од особина карактеристичних за Balkan Sprachbund" (MIŚESKA TOMIĆ 2006: 2, фуснота бр. 4).

Граматикализација демонстратива у одређени члан представља дијахронијску језичку универзалију, што је у типолошким студијама посведочено на огромном броју језика ${ }^{12}$ (за семитске, нигеро-конгоанске и језике америчког континента, в. GREENBERG 1978; за романске и германске језике, в. HARRIS 1980). Џозеф Гринберг (Joseph Greenberg) (1978) показује да се

\footnotetext{
${ }^{10}$ Ова хипотеза спада у теорије тзв. суперстрата.

${ }^{11}$ Полидефинитне номиналне фразе у грчком имају слободан ред речи, те рестриктивну и интерсективну интерпретацију (LEKAKOU \& KARATSAREAS 2015).

${ }^{12}$ Иако има и случајева граматикализације одређеног члана од посесивних заменица, и то у уралским и делу туркијских језика (SCHROEDER 2006).
} 
даља граматикализација демонстратива, тј. одређеног члана одвија у три фазе. После прве фазе, у којој демонстратив постаје члан, следи његова граматикализација у негенерички маркер, након које члан губи семантику одређености и постаје пуки маркер припадности класи именица. Хокинс (HAWKINS 1994), Дисел (DIESSEL 1999) и Лајонс (LYONS 1999) Гринбергов први циклус даље деле на две подетапе, у којој је кључно да демонстратив изгуби деиктички аспект, те да се сведе на чист анафорички маркер. Оно по чему се постпозитивни одређени члан у тимочколужничком (и заплањском) варијетету и македонском језику разликује од осталих балканских језика јесте чињеница да није граматикализован само из једне, већ три класе показних заменица (mәj/овәј/онәј $\rightarrow$ әm/əв/əн), те да и даље може имати демонстративну семантику (БЕЛИЋ 1905: 300-308; КОНЕСКИ 1986: 150-154). Са друге стране, за разлику од македонског, употреба одређеног члана није обавезна у анализираним варијететима. Све ове чињенице нам указују на то да је граматикализација члана из демонстратива и даље in status nascendi. Као што ћемо показати у поглављу које следи, опаска да члан има и семантику показне заменице је често истицана у дијалектолошкој литератури о тимочколужничком дијалекту још од Белићеве (1905) знамените монографије „Дијалекти источне и јужне Србије”. Остаје, међутим, истраживачко питање: Постоје ли можда контексти у којима су изворним говорницима прагматички прихватљиви само постпозитивни чланови, или искључиво показне заменице?

\section{3. Члан и демонстративне заменице у дијалектолошкој литератури}

Већ смо поменули да се у домаћој дијалектолошкој литератури још од Белића (1905) указује на то да је „врло важна особина ових дијалеката (...) употреба демонстративних заменица у значењу члана" (БЕЛИЋ 1905: 300). У поглављу насловљеном „Додатак облицима деклинације”, Белић се, пре свега, бави питањем историје члана на читавом простору призренско-тимочког дијалекта, постављајући хипотезу да је постпозитивни члан био особина свих његових говора, па тако и јужноморавских, јер је присутан у говору читаве источне Србије и Македоније, али да није немогуће да је члан „могао добити” и под утицајем бугарског језика ${ }^{13}$ (ибид.). Остављајући по страни питање ове реконструкције, осврнућемо се на Белићев опис употребе члана и демонстратива.

\footnotetext{
13 Имајући у виду помињану Гринбергову дијахронијску универзалију и чињеницу да постоји систематска појава да језици упрошћују деклинациони систем а демонстративе (или посесиве) граматикализују у одређени члан, СТАНКОВИЋ (2015б) разматра могућност да ни једна ни друга претпоставка нису тачне, већ да се члан појављује као резултат унутрашњих процеса морфолошке симплификације и аналитизације, посведочених у стотинама других индоевропских и неиндоевропских језика.
} 
„Обично се не чини разлика између употребе члана и демонстративне заменице онако како треба: мисли се да једно искључује друго, а то је нетачно. Ови су дијалекти најбољи доказ за то. У њима се употребљавају показне заменице у истом положају, само - разуме се - не у исто време, и као демонстративне заменице и као члан. Најчешће се, и готово једино, употребљава као члан заменица $m b^{[14]}, m a$, mo. Изгледа по свему, а особито по релативној усамљености примера употребе демонстративних заменица у значењу члана, да се заменица $т ь$ првобитно употребљавала у значењу члана, а да су се неке њене особине пренеле и на друге демонстративне заменице.” (БЕЛИЋ 1905: 300-301)

У наставку аутор указује на то да члановани придеви увек у свом саставу имају и наставак одређеног вида $u$ без обзира на то да ли се ради о форми әm, әв или -ән, што „особито лепо показује” да се заменица $m$,употребљава као члан", а што се не може тврдити за остала два демонстратива (ов и он $)^{15}$, ,jер се, када се оне употребљавају уз именице и придеве, још непрестано врло лепо чува њихово показно значење.” (БЕЛИЋ 1905: 301).

„Оне [заменице $о в$ и $о н]$ се стављају насупрот заменици $m$, која такође није још никако изгубила своје показно значење. Према томе: дете́mo, поред обичног значења das Kind значи и тој дете́ dieses Kind, док дете́во и дете́но увек значе ово́j demé и оно́j дете́. И нигде се показно значење ових заменица није свело на право, једино, без икаквих нијанса, чланско значење.” (ибид.)

У петом поглављу рада осврнућемо се на ове Белићеве оцене, показати да је у праву када каже да постпозитивни чланови әв и -ән увек имају додатну „нијансу у значењу”, а потом покушати да утврдимо у којим контекстима говорници искључиво користе демонстративе, а у ком само постпозитивне одређене чланове. Пре тога ћемо представити ставове изнете у остатку дијалектолошке литературе која обрађује говоре тимочко-лужничке и заплањске зоне, а који нимало не одступају од Белићевих анализа.

Тако Маринко Станојевић у студији „Северно-тимочки дијалекат” пише да се члан ,често једначи са демонстративним заменицама, од којих је он и постао”. (СТАНОЈЕВИЋ 1911: 410). Аутор оцењује да је ова појава у севернотимочком дијалекту „свакако врло стара, као што ни губљење номиналних облика није скорашње. Можда се [члан] развио овде самостално, али је могућ и утицај бугарског језика.” (ибид.).

Слично, у раду „О пореклу и особинама пиротског говора (и осталих говора српског југоистока)" Павле Ивић одређене чланове назива заменичким постпозицијама (ИВИЋ 1979: 198), што нам посредно говори о ауто-

\footnotetext{
${ }^{14}$ Према реиздању Белићеве монографије ЗУНС-а из 1999. године, демонстратив мушког рода једнине има (српскословенски?) наставак -b.

${ }^{15}$ СТАНКОВИЋ (2015а) показује да се придевским видом не маркира само тзв. прагматичка одређеност, тј. поменутост или старост у дискурсу номиналног референта, те да је употреба одређеног придевског вида обавезна у случају демонстративности.
} 
ровој интерпретацији члана као демонстратива са другачијом синтаксичком дистрибуцијом од уобичајене, пренонималне. Као и у Белићевој пионирској студији, Ивића пре свега занима начин на који су добијени различити облички наставци трију серија демонстративних заменица - да ли се ради о префонологизацији апсолутним гласовним променама, аналошким процесима или страном, тј. бугарском утицају.

Недељко Богдановић у монографији „Говори Бучума и Белог Потока” пише да је сврха чланске морфеме у овим говорима у детерминисању појмова по степену присутности, односно блискости, и удаљености од лица које говори. „Тај критеријум обухвата како просторну, тако и преносну присутност/познатост предмета о ком се говори, и то тростепеност те познатости (не постоји нешто што би било адекват неодређеном члану у језицима који познају члан)" (БОГДАНОВИЋ 1979: 74). Остатак поглавља „Чланска морфема” аутор посвећује питањима наставака у општем падежу (брата́mога, куmújymy), врстама речи иза којих се ова морфема може наћи, те проблему односа облика паметнијат и паметнити ${ }^{16}$. Остаје нејасно о каквој би се „тростепености познатости” могло радити, те одакле тврдња да „не постоји нешто што би било адекват неодређеном члану у језицима који познају члан” када у овим говорима, као уосталом и у остатку српског језичког простора, постоје неодређена заменица неки/нека/неко и некардинална, детерминаторска употреба броја један/једна/једно, што свакако јесу „,адеквати неодређеном члану”

О последњем поменутом питању тзв. номиналне индетерминације Љубисав Ћирић пише у студији „Говор Лужнице”, констатујући да се она у овим говорима „изражава најчешће неодређеном заменицом: дете́ - некво́ (или некоје́) дете́ (испор. у немачком ein Kind, у франц. un garçon).” (ЋИРИЋ 1983: 80). Аутор ову зону дели на две области: Лужницу, у којој је уобичајена „детерминација заменичким постпозицијама” и анафорском употребом демонстратива, и лужничко Заплање, у коме се искључиво појављује други облик упућивања, дакле, без одређеног члана. „Системом постпозитивних морфема (...) изражава се и демонстративна функција (...) али то, релативно, ретко бива у конкретној говорној ситуацији. Чешћа је, и то несразмерно, чланска функција (...)” (ЋИРИЋ 1983: 80). Ћирић оцењује да чланску функцију има скоро искључиво постпозиција -әт.

„Кад нпр. Лужничанин каже: испи си рећијуmу да ти не истине (...) он мисли на ракију која је заиста ближа саговорнику, него њему, тј. говорном лицу. Или: малко

\footnotetext{
${ }^{16}$ Када је у питању семантичка дистинкција између двеју форми (големијат и големити), односно став Маринка Станојевића (1911) да први облик представља неодређени, а други одређени вид придева, сагласни смо са оценом Богдановића да је међу њима немогуће утврдити „разлику у значењу“ (БОГДАНОВИЋ 1979: 76).

17 У одговарајућем окружењу употреба неодређених детерминатора је обавезна и у српском језику (в. STANKOVIĆ 2017).
} 
ли се појавиш одовде до шумакан ДС, реч је о шумарку који је заиста просторно подједнако удаљен и од говорника и од саговорника. То исто имамо и у примеру: ајде да одведемо девојчево у Ваву Рад, девојчево (= ово девојче) је просторно најближе говорном лицу. У овим примерима се, дакле, огледа демонстративна функција чланске морфеме. Међутим, у примерима: оне научиле, научиле овцеmе; на бабу купи кожув момчето; па препрегне волатога ДС и сл. - свуда се ради о већ спомињаним појмовима, познатим а неприсутним. Или, још бољи примери за чланску употребу $m$, ma, то: првњо дете ми е тој Милата; а тога Bojymy неје попуштала тај штото умре Рад. И Мила и Воја (властите именице, уз које по правилу не стоји члан, јер су самим тим што су властите довољно и детерминисане) су пре тога спомињани, али не и присутни.” (ЋИРИЋ 1983: 80)

Ово је најдетаљнија и, чини се, најпрецизнија анализа ${ }^{18}$ употребе демонстратива и постпозитивног члана у досадашњој литератури. Оваква се оцена, нажалост, не би могла дати за опис употребе одређеног члана који у раду „Говор Црне Траве и Власине” нуди Вилотије Вукадиновић. У њему аутор спомиње Белићеве (1905) налазе о географској дистрибуцији одређеног члана, а потом пише да ова категорија „у говору Црне Траве и Власине има двоструку функцију: одређивање присутности/одсутности ${ }^{[19]}$ и удаљености од говорног лица, односно демонстративну и чланску функцију.” (ВУКАДИНОВИЋ 1996: 197). Након навођења бројних примера у којима је забележен члан (без ширег контекста, што је мањкавост свих наших дијалектолошких радова), аутор само констатује како „ово показује колико су демонстративне нијансе живе у “члану”” (ВУКАДИНОВИЋ 1996: 203).

Станислав Станковић (2008) у монографији „Границе призренскотимочких говора у власотиначкоме крају" објашњава да, попут локалног јужноморавског идиома, власотиначки заплањски говор „не зна за постпозитивну употребу демонстративних заменица”, те да су „чланске морфеме забележене на подручју власотиначког ЗГ [заплањског говора] (...) у којему се пак, у поређењу са суседним лужничким говорима, само спорадично чују". (СТАНКОВИЋ 2008: 71-72). Ове су тврдње поткрепљене и одговарајућом картом, на којој су представљене области у којима се употребљава само члан, или само демонстративне заменице, поред граничних области у којима се паралелно користе и једна и друга категорија (ибид.: 96).

\footnotetext{
18 Занимљива је тврдња да се употребом члана иза властитих именица маркира поменутост, тј. старост у дискурсу номиналног референта, јер би ово значило да се члан не може употребити приликом њиховог увођења у дискурс. Пуно је језика у којима се члан регуларно појављује и уз nomina propria - такав је случај са новогрчким, те колоквијалним немачким и италијанским, између осталог - те уколико је тачно горепоменуто, имали бисмо занимљив случај да је употреба члана уз властите именице регулисана помоћу тзв. јаке и слабе одређености (strong and weak definiteness) (POESIO 1994; CARLSON \& SUSSMAN 2005). Аномни рецензент рада напоменуо нам је да се одређени члан употребљава уз властита имена и у ромском језику, на шта се посебно захваљујемо.

${ }^{19}$ Није јасно како то „одсутност” може утицати на употребу чланова, ни када су у питању демонстративне, нити, пак, дефинитне (одређене) интерпретације.
} 
На послетку, у раду „Просторна расподела фреквенције постпозитивног члана у тимочком говору” Теодора Вуковић и Тања Самарџић напомињу да постоји велика просторна варијација у употреби члана у тимочком говору: „Говорници неких села члан користе врло учестало, док га неки говорници не користе уопште.” (ВУКОВИЋ И САМАРЏИЋ 2018: 183). Оне објашњавају да нема података који се од трију облика и колико често јавља у савременом говору, , а још мање о начину његове употребе. За разумевање природе члана неопходно је испитати у којим се условима он јавља, тим пре што се он у тимочким говорима јавља са израженом варијабилношћу чији степен и узроци до сада нису испитивани.” (ибид: 182). Дакле, за разлику од нашег истраживања, у фокусу монографије Станислава Станковића и рада Вуковић и Самарџић је просторна расподела фреквенције употребе члана (и показних заменица, код Станковића), а не конкретни типови контекста у којима говорници користе искључиво постпозитивни члан или само демонстративе.

Овим је исцрпљен кратки списак радова у домаћој дијалектологији који се, између осталог, баве описом и анализом употребе одређеног члана и демонстратива у говорима тимочколужничке и сврљишкозаплањске зоне. У централном, петом поглављу рада представићемо резултате нашег истраживања, који ће показати да се у урбаном пиротском идиому постпозитивним чланом маркирају старост у дискурсу референта релационих именица, те јединственост, асоцијативна анафора и генеричке именичке синтагме, док се демонстративне заменице редовно појављују приликом просторног упућивања у контрастивним и емфатичким неепитетским контекстима. Пре тога ћемо ћемо образложити на каквој се говорној и лингвистичкој интуицији заснива наше истраживање, те описати примењену методологију.

\section{1. Интуиција иза истраживања}

Полазна интуиција у истраживању јесте идеја да постоји значајна семантичка разлика између одређеног члана, са једне стране, и демонстратива, са друге. Наиме, два најзначајнија приступа дефинисању одређеног члана у формалносемантичкој литератури крећу или од познатости/поменутости/ старости у дискурсу референта именичке синтагме (CHRISTOPHERSEN 1939), или од јединствености номиналног референта у датом физичком или језичком контексту (RUSSELL 1905) (о обама приступима детаљније ће бити речи у потпоглављима 5.1 и 5.2). Суштина и једне и друге групе дефиниција је идеја да се употребом одређеног члана маркира да постоји један и само један именички референт, који је стар у дискурсу, једини у датом окружењу саговорника или је на неки други начин могуће закључити шта чини укупни номинални денотат. Из тих разлога логично је очекивати да у овим и сродним контекстима, попут генеричких именичких синтагми и асоцијативне анафоре, говорници преферирају одређени члан уместо показ- 
них заменица. Са друге стране, када су у питању демонстративи (нарочито у случају показних заменица овај и онај), неретко у физичком или језичком контексту постоји више од једног потенцијалног референта, па се употребом демонстратива обележава (топикална или фокална) контрастивност (о контрастивности в. више у подсекцији 5.5). Из тих разлога очекујемо да hе се говорници у контрастивном окружењу пре одлучити за показну заменицу, него за постпозитивни члан. Разуме се, овим не искључујемо ни могућност постојања случајева који не представљају ни један ни други крај претпостављеног континуума, што дозвољава говорницима да у истом контексту подесно ${ }^{20}$ употребе и демонстратив и одређени члан, те о чему ће такође више речи бити у наредном поглављу.

\section{2. Методологија истраживања}

Наше истраживање заснива се на двема методама, корпусној и експерименталној. У првој фази испитивања употребе постпозитивних чланова и демонстратива прегледали смо сву транскрибовану грађу доступну у дијалектолошкој литератури (БЕЛИЋ 1905; СТАНОЈЕВИЋ 1911; БОГДАНОВИЋ 1979; ЋИРИЋ 1983; ЗЛАТКОВИЋ 1988; ВУКАДИНОВИЋ 1996; СТАНКОВИЋ 2008), те досад транскрибовани корпус забележен у оквиру пројекта „Чувари нематеријалне баштине тимочких говора” (2015-2017), финансиран од стране Министарства образовања, науке и технолошког развоја Републике Србије (ЋИРКОВИЋ 2018). Из дијалектолошке грађе ексцерпирано је 127, а из транскрибованог тимочког корпуса нешто више од 850 реченица у којима се појављују постпозитивни чланови и демонстративне заменице. Како смо већ поменули, примери које наши дијалектолози анализирају приликом описа стања у анализираним говорима никада нису дати у ширем језичком контексту (најчешће су ексцерпирани као именичка синтагма или клауза), те је немогуће изводити икакве закључке о томе зашто се говорник одлучио за употребу једне или друге језичке јединице. Кад су у питању транскрибовани текстови, истраживач је у могућности да идентификује услове под којима се јавља неки језички израз, али не и да испита да ли би у истом контексту могао бити у употребљен други, алтернативни језички израз. Према томе, на основу корпусне методе могли смо да проверимо нашу полазну интуицију, описану у претходном потпоглављу, али не и да изнесемо децидиране тврдње о искључивој подесности коришћења одређене категорије у датом контексту. ${ }^{21}$

\footnotetext{
${ }^{20}$ Ово би био најближи превод прагматичког термина felicity (conditions) Џона Л. Остина (Jonh L. Austin), творца теорије говорних чинова, којим овај аутор оперише у серији универзитетских и јавних предавања постхумно објављених под насловом „How to do things with words" (AUSTIN 1962: 14).

${ }^{21}$ Примери из ексцерпиране грађе су коришћени у оригиналу или су адаптирани приликом формулисања задатака (в. објашњење дато у наставку потпоглавља).
} 
Из тих разлога смо у другој фази истраживања применили експерименталну методу, прецизније, методу процене прихватљивости језичког исказа у датом контексту на скали Ликертовог типа са вредностима од -1 до 1 , при чему вредност ,-1” означава став „неприхватљиво”, оцена „0” исказ „полуприхватљиво”, док се вредношћу „1” изриче став „прихватљиво”. У истраживању је учествовало тридесеторо испитаника (по 15 припадника оба пола), особа млађих од 50 година које су становници Пирота 22 . Определили смо се за субјекте ове старости, те житеље урбаних градских зона само због сложене природе експеримента, у којој испитаник треба да замисли одређени физички или језички контекст, а затим процени да ли би и у којој мери било подесно употребити неки језички израз. Овакав ниво апстраховања није уобичајена пракса за говорнике, па их може збунити, што води неуспелом експерименту или неадекватном оцењивању прагматичке прихватљивости. Поред овог недостатка, те чињенице да се од испитаника тражи да користе језик „под вештачким условима”, велики проблем у оваквим испитавањима представља факт да један број говорника није навикао на то да сопствени дијалекат види у писаној форми, јер се, под утицајем ригидног прескриптивизма домаће језичке политике (FILIPOVIĆ 2011; FILIPOVIĆ \& VUČO 2012; STANKOVIĆ \& STEFANOVIĆ 2019), употреба локалног дијалекта своди на неформалну усмену комуникацију. Из истих разлога је врло честа појава беспотребан страх од истраживања, бојазан код испитаника да ће бити исмејани, те да се оцењује њихов степен „непознавања језичке норме”, што неретко води хиперкорекцији (СТАНКОВИЋ 2016).

За сваки од шест типова анализираних контекста (старост у дискурсу, јединственост, генеричност, асоцијативна анафора, контрастивност, емфатичност), припремљено је по шест примера који укључују демонстративе и члан (дакле, по 12 примера). Ово у укупном збиру даје 72 примера, чему треба додати и једнак број филера, резултујући бројком од 144 рандомизирана задатка. Пилот-истраживање са пет субјеката показало је да овако велики број задатака није могуће урадити без замора испитаника, што без сумње води нерелевантним резултатима. Из тих разлога је истраживање реализовано у две сесије, при чему је између двеју сесија направљена пауза од 30 дана. Сви испитаници су изашли у сусрет нашој молби да два пута раде (различито) истраживање, чиме смо, надамо се, добили релевантне резултате, без бојазни да је дошло до евентуалног примовања.

Напоменућемо да циљне реченице представљају адаптације примера из литературе или реченице специјално конструисане за потребе истражи-

\footnotetext{
${ }^{22}$ Из тих разлога се емпиријска сазнања у раду односе, пре свега, на урбани говор Пирота, али би се могло претпоставити да важе за читаву тимочко-лужничку зону, под условом да, када је у питању подесност употребе члана и демонстратива у различитим типовима контекста, не постоји значајна разлика у говорној интуицији међу испитаницима који припадају различитим генерацијама или говорним варијететима, што је у значајној мери потврђено упоређивањем доступне дијалекатске грађе и резултата̂ наших експеримената.
} 
вања, те да су све претходно проверене код изворних говорника који нису учествовали у испитивању. Под адаптацијом подразумевамо замену аутентичних чланованих форми синтагмама са показним заменицама (нпр. козата $\rightarrow$ тај коза) и обрнуто. Сви примери које ћемо представити у петом поглављу рада били су оцењивани од стране наших субјеката. У наредном одељку презентоваћемо добијене резултате и понудити одговарајућу интерпретацију података.

\section{1. Старост у дискурсу}

Како је већ било речи, у формалносемантичкој литератури се питању дефинисања одређености најчешће приступа из угла поменутости (познатости, старости у дискурсу) или категорије јединствености. Паул Кристоферсен (Paul Christophersen) је дански лингвиста који је први употребу одређеног члана у енглеском повезивао са познатошћу (familiarity), објашњавајући је следећим речима: „Говорник мора знати на коју индивидуу мисли; интересантно је да the-форме подразумевају да и саговорник то зна, такође.” (CHRISTOPHERSEN 1939: 28). Ову је идеју Ирен Хајм (Irene Heim) касније формализовала у својој семантици промене фајла (File Change Semantics) (HEIM 1983; 1988). И у домаћој литератури се употреба одређеног придевског вида стандардно објашњава појмовима познатости и поменутости (MARETIĆ 1899; ФЕКЕТЕ 1969/73; СТЕВАНОВИЋ 1986). Иста је ситуација и са употребом одређеног члана у дијалектолошким радовима о тимочколужничком и сврљишкозаплањском, како је већ представљено у трећем поглављу рада.

Излишно је објашњавати да се старост у дискурсу увек може маркирати и анафорском употребом демонстратива, што важи и за анализиране говоре (на шта је указивао и Ћирић (1983), в. треће поглавље), али и за остале српске дијалекте. Оно што до сада није примећено јесте чињеница да овакво дискурсно понашање, за разлику од апсолутних именица, не показују тзв. релационе именице (relational nouns). Себастијан Лебнер (Sebastian Löbner) релационе именице дефинише као именице које имају један референцијални аргумент и један или више релационих аргумената, што их битно разликује од концепта апсолутних именица, које описују своје потенцијалне референте независно од било којих корелата које треба спецификовати (LÖBNER 2015: 3). Тако, на пример, иако именичка синтагма ,женска особа" (која у свом саставу има апсолутну заједничку именицу особа и придев изведен од апсолутне заједничке именице жена) и релациона именица „ћерка” имају (или могу имати) исту екстензију, „женска особа” је особа женског пола захваљујући особинама (properties) којих је носилац по себи, док концепт „ћерка” увек подразумева и релациони однос „дете-родитељ” у својој структури. Релациони односи, поред сродства, подразумевају и концепте 
неодвојивог дела (глава), друштвеног односа (меф), догађаја (рођење), особине (узраст), затим апстрактне корелате попут „име” и др. (ибид.).

Реферисање на релационе именице које су уведене у дискурс по правилу се врши помоћу постпозитивног члана. Као илустрација ће нам послужити део из Белићеве (1905) грађе прикупљене у Пироту, забележене према казивању девојке Милке из Тијабаре:

(4) Тетка ${ }_{[i]}$ си позва царевотога сина у њи, на госје. Он дошә л. Она че га послужи (девоћа). Облекла пембелију, узела такә в послужевник, пембелију. Частила га сә с ракију. Соблекла пембелију, востан, облече плав-модар (востан), па узе плав-модар послужевник, па га послужи сә с каве [...] Она ce изнаsадила ноsад та падла чашата, те се строшила, а тетката ${ }_{[i]}$ ока по измићаркуту: „буди су ти отпадле руќете, а ти неси ћорава, што не држиш.” (БЕЛИЋ 1905: 425-426) (дискурс-старо)

Говорница прво у дискурс уводи релациону именицу тетка, да би потом, у каснијем развоју дискурса, поново реферисала на њу постпозитивним чланом тетката (што је у тексту маркирано индексом $i$ ). У потпуно истом окружењу, за изворне говорнике је прагматички неприхватљиво да анафорски употребе демонстративну заменицу. Наиме, свих 30-оро наших испитаника је оценило потпуно депласираним показне заменице у оваквом контексту (обележено симболом „\#”) уколико језички израз нема експресивну интерпретацију (в. објашњење у потпоглављу 5.6):

(5) Тетка $_{[i]}$ си позва царевотога сина у њи, на госје. Он дошә л. Она че га послужи (девоћа). Облекла пембелију, узела такә в послужевник, пембелију. Частила га сә с ракију. Соблекла пембелију, востан, облече плав-модар (востан), па узе плав-модар послужевник, па га послужи сә с каве [...] Она се изнаsадила ноsад та падла чашата, те се строшила, а \#\{ова(j) тетка $\}_{[i]}$ / $\{\# \underline{\text { тај тетка }}\}_{[i]} /\{\text { \#она(j) тетка }\}_{[i]}$ ока по измићаркуту: „буди су ти отпадле руќете, а ти неси ћорава, што не држиш."

Према томе, (емфатички неутрално) маркирање дискурс-старих референата релационих именица врши се искључиво помоћу постпозитивног члана, а никада анализираним анафорским заменицама. Као што ћемо показати у последњем потпоглављу овог дела рада, анафорске заменице у овом окружењу увек имају и додатно експресивно читање.

\section{2. Јединственост}

Описујући употребу одређеног члана у енглеском језику, енглески филозоф и математичар Бертранд Расел (Bertrand Russell) препознаје један занимљив феномен, а то је чињеница да се одређеним чланом имплицира јединственост денотата у космосу (RUSSELL 1905), односно, у релевантном контексту, о чему се изводе прагматичке импликације (SZABÓ 2000: 3), и то независно од дискурсног статуса референта, тј. да ли је претходно поменут или не. Илустроваћемо ово на примеру суперлатива, који пресупонира 
постојање најмање три именичка референта, међу којима је само један носилац придевом денотиране особине у највећој мери ${ }^{23}$. Без обзира на то што укупни номинални денотат није део дискурса, у урбаном пиротском варијетету његова јединственост може бити маркирана постпозитивним чланом, што показује следећа реченица ${ }^{24}$.

(6) За попа се удала најубавата девојћа у село. (јединствено)

У другом поглављу рада већ смо поменули да се одређени члан у анализираним говорима не употребљава доследно, те је одатле логично очекивати да ће у истом контексту испитаницима у потпуности бити прихватљива и нечланована синтагма:

(7) За попа се удала најубава девојћа у село. (јединствено)

Међутим, у овом окружењу прагматички је потпуно депласирано употребити неки од демонстратива, тј. анафорских заменица, будући да би се њима маркирала поменутост:

(8) За попа се удала $\{$ \#овај / \#тај / \#онај $\}$ најубава девојћа у село. (jeдинствено)

Свих тридесет испитаника је исказ у (8) вредновало оценом -1 у задатом окружењу. Према томе, у урбаном пиротском варијетету јединственост дискурсновог номиналног референта може бити обележена само постпозитивним чланом, а никако и анафорски употребљеном показном заменицом, будући да би она пресупонирала да је укупни денотат већ уведен у дискурс. Приметимо да је у примерима (6)-(8) употребљена апсолутна именица девојћа. Дакле, за разлику од поменутости, код које постоји ограничење о оваквој употреби само у скупу релационих именица, приказана веза категорије јединствености и постпозитивног члана односи се и на апсолутне и релационе именице.

\section{3. Генеричност}

У другом поглављу рада већ смо говорили о Гринберговим (1978) трима етапама граматикализације демонстратива у одређени члан. Како овај аутор описује, након етапе у којој демонстратив постаје члан, следи његова граматикализација у негенерички маркер, да би коначно постао обичан маркер припадности класи именица. Из овога се може извући закључак да су генеричке именичке синтагме маркиране одређеним чланом за време чита-

\footnotetext{
${ }^{23}$ Из истих разлога синтетички суперлатив и компаратив придева у српском језику имају само облик одређеног вида, без обзира на то да ли је укупни денотат део дискурса.

${ }^{24}$ Сви примери за које није наведен извор представљају адаптације примера из литературе или су конструисани за потребе спроведеног истраживања и проверени су код изворних говорника.
} 
вог првог циклуса граматикализације. Постоји и логична позадина овом феномену, а то је чињеница да се генеричним изразима максимизовано упућује на све представнике врсте, па се подскуп јединственог денотата проширује на читав скуп истоврсних референата. И заиста, у језицима са чланом који је и даље у првој фази граматикализације одређени члан је обавезан у генеричким изразима, нарочито када се ради о једнини бројивих именица ${ }^{25}$ :

(9) L’ordinateur a changénos vies. (генеричко) (фра.) одр.члАн компјутер пом.глА. ${ }^{26}$ променио наши животи „Компјутер је променио наше животе”

Иако употреба члана није обавезна у тимочко-лужничком, забележено је доста примера у којима се генеричност маркира постпозитивним чланом, што је и очекивано, с обзиром на то да је граматикализација члана из демонстратива и даље у првој фази. Ограничени простором, ову појаву ћемо илустровати двама ексцерпираним примерима:

(10) Ако быши козата, не быше роговети. (ЗЛАТКОВИЋ 1988) (генеричко)

(11) Бугарите ни брајћа. (СТАНОЈЕВИЋ 1911) (генеричко)

Разуме се, у истом окружењу је потпуно прихватљиво употребити и нечланован израз:

(12) Ако быши коза, не бьше рогове. (генеричко)

(13) Бугари ни брајћа. (генеричко)

Међутим, у генеричким контекстима је потпуно прагматички депласирано употребити демонстративноанафорску заменицу, јер би читава синтагма добила или дефинитну (одређену), или демонстративну интерпретацију, али никако не би могла имати и генеричко читање:

(14) Ако бьши \#\{тај коза $\}$, не быше \#\{тиј рогове $\}.$ (генеричко)

(15) \#\{тиј Бугари $\}$ ни брајћа. (генеричко)

Као и у случају јединствености денотата, и примере са генеричким номиналним изразима су сви изворни говорници урбаног пиротског варијетета оценили најнижом оценом -1 , пошто би присуство показне/анафорске заменице имплицирало присуство/поменутост референта у физичком или језичком контексту.

25 Небројиве масене именице и множинске форме бројивих именица прве показују тенденцију губљења члана у генеричким изразима. Први случај илустроваћемо примером из немачког, а други примером из енглеског језика:

(1)

$\begin{array}{ll}\text { Wasser } & \text { ist } \\ \text { вода } & \text { je }\end{array}$

Animals are

животиње су

${ }^{26}$ пом.глА. = помоћни глагол wertvoll. (генеричко) (нем.)

драгоцена

precious. (генеричко) (енг.) 


\section{4. Асоцијативна анафора}

Асоцијативна анафора је специфичан облик анафорског реферишућег израза, који има следећа својства:

„(А) упућује на објекат (референта) који је нов у дискурсу, тј. није експлицитно поменут у претходном контексту;

(Б) у потпуности може бити интерпретиран референцијално само на основу информација које су уведене у дискурс у ранијим фазама комуникације (...), што оправдава употребу термина анафора. Асоцијативна анафора, према томе, јавља се када је реферишући израз интерпретативно зависан од специфичних информација пружених у претходном језичком контексту, а које нису кореференцијалне са неким другим језичким изразом." (APOTHÉLOZ \& REICHLER-BÉGUELIN 1999: 365)

У језицима са чланом асоцијативна анафора је увек праћена употребом одређеног члана. Занимљиво је да исто понашање показује и придевски вид у српском језику. У следећем примеру прво се у дискурс уводи кућа, а затим се говори о крову као делу истог објекта, што је обележено одређеним придевским видом модификатора (асоцијативна анафора маркирана је симболом , $i$ А” у индексу). Употребом неодређеног вида у истом окружењу неопходно би се упућивало на неки други, дискурснови референт одговарајућег израза, који није партитивно везан за реферишуће изразе из претходног контекста:

(16) $[\text { Кућа Петровића }]_{i \AA}$ била је веома стара. [\{Влажни / \#Влажан $\}$ $\underline{\text { кров }}]_{i \mathrm{~A}}$ био је прекривен маховином.

Иста је ситуација и са дистрибуцијом одређеног члана, који се мора појавити уз асоцијативноанафорске изразе, јер би у противном израз партитивно имао дискурс-ново читање. Пример (16) на македонском језику гласио би овако:

(17) $[\text { Куќата на Петровиќ }]_{i \mathrm{~A}}$ беше многу стара. [\{Влажниот / \#Влажен $\}$ $\underline{\text { кров }}]_{i \mathrm{~A}}$ беше прекриен со мов. (мак.)

Потпуно је иста ситуација и са тимочколужничким дијалектом, уз ту разлику да би факултативност члана дозволила да номинална фраза не буде чланована. Ипак, у оваквим окружењима увек би се појавио одређени вид придева, баш као и у остатку српског језичког простора:

(18) [Кучата на Петровичи $]_{i \mathrm{~A}}$ била је много стара. [\{ ни / \#Влажән кров $_{i \mathrm{~A}}$ бил је прекри(ј)ен сәс маховину.

У грађи смо наишли на занимљив пример асоцијативне анафоре, у коме се прво помиње брашно, а потом израз вречете (,вреће”, у којима се брашно складишти), маркиран постпозитивним чланом: 
(19) Ако немаш брашно ${ }_{i \mathrm{~A}}$, истреси вречете ${ }_{i \mathrm{~A}}$ (ЗЛАТКОВИЋ 1988)

Разуме се, асоцијативноанафорски израз могао би стајати и без члана (20), али се никако не би могао маркирати демонстративом/анафорском заменицом (21).

(20) Ако немаш брашно ${ }_{i \mathrm{~A}}$, истреси врече ${ }_{i \mathrm{~A}}$.

(21) Ако немаш брашно ${ }_{i \mathrm{~A}}$, истреси $[\{\# \text { овеј / \#теј / \#онеј }\} \text { врече }]_{i \mathrm{~A}}$.

Приликом нашег истраживања претпоставка да се асоцијативна анафора може обележити само постпозитивним чланом је у потпуности потврђена за демонстративе овәј и онәј, који су редом били оцењивани најнижом оценом. Међутим, у случају демонстратива тај шесторо испитаника дало је највишу оцену, 1, док су сви остали испитаници овакву употребу одбацили, оценивши је оценом -1. Разлог овако драстично различитој евалуацији је могућност да се у емфатичким контекстима добије и додатна експресивна интерпретација, што је већ поменуто у потпоглављу 5.1, те о чему ће више бити речи у последњем потпоглављу овог дела рада, 5.6. Пре тога осврнућемо се на феномен искључиве употребе демонстратива у контрастивном окружењу.

\section{5. Контрастивност}

Контрастивност је појава везана за информацијску структуру исказа, појам који одговара значењу термина aktuální členění větné Виљема Матезијуса (Vilém Mathesius) или Satzperspektive, тј. функционална реченична перспектива Јана Фирбаса (Jan Firbas). У лингвистичкој литератури се барата већим бројем, мање или више поклапајућих, парова термина којима се дефинише артикулација целокупног исказа - тема:рема, тема:коментар, тема:фокус, пресупозиција:фокус, позадина:фокус, дато:ново, појмовни субјекат:појмовни предикат - при чему се сви они могу класификовати с обзиром на то да ли се информативност неког исказа одређује у односу на реченично/текстуално окружење или у односу на дискурс. Највећи број аутора слаже у погледу употребе појма контрастни, који је у лингвистику увео Волис Чејф (Wallace Chafe) (CHAFE 1976). „Појам контрастивног фокуса зависи (а) од неког домена дискурса који већ постоји или који одређује сам оператор фокуса, или (б) од скупа могућности, од којих фокализовани елемент бира један.” (HALUPKA-REŠETAR 2011: 13). Тако, постоји разлика у погледу контрастираног скупа могућности у следећим двама исказима:

(22) Марија је обукла црвену хаљину. (контрастивно)

(23) Марија је обукла щрвену хаљину. (контрастивно)

Док се у (22) црвена хаљина контрастира у односу на друге црвене одевне предмете, у примеру (23) контрастира се црвена према хаљинама друге боје. 
У пододељку 4.1 већ смо помињали да неретко у физичком или језичком контексту постоји више од једног потенцијалног референта, да се употребом демонстратива може обележавати (топикална или фокална) контрастивност, те да очекујемо да ће се говорници у контрастивном окружењу пре одлучити за показну заменицу, него за постпозитивни члан. Наиме, употреба тзв. логичког акцента на демонстративу увек изазива контрастивне ефекте, што важи за већину језика света, па тако и српски. Било би прагматички потпуно депласирано да у просторији у којој постоји само једна књига изговоримо (24), будући да би контрастивни фокус на демонстративу пресупонирао да постоји макар још један номинални референт:

(24) [у физичком контексту са само једном видљивом књигом] \#Додај му ту књигу. (контрастивно)

Имајући у виду речено, сасвим је логично очекивати да ће се фокализовани демонстративи природно јавити у контрастивним окружењима, што, разуме се, у потпуности важи и за пиротски варијетет:

(25) Додај ми ђу онуі, а не туј праску. (контрастивно)

(26) Додај ми ђу овуі, а не туіпраску. (контрастивно)

(27) Додај ми ђу онуі, а не овуіпраску. (контрастивно)

Оно што, међутим, није прихватљиво интуицији изворних говорника јесте да се у контрастираном контексту употреби постпозитивни члан:

(28) \#Додај ми ђу праскуну, а не праскуту. (контрастивно)

(29) \#Додај ми ђу праскуву, а не праскуту. (контрастивно)

(30) \#Додај ми ђу праскуну, а не праскуву. (контрастивно)

Свих 30 испитаника оценило је примере попут (28)-(30) најнижом оценом, -1 . Међутим, треба нагласити да употреба постпозитивних чланова није депласирана када се контрастирају разноврсни објекти чија је позиција другачија у односу на учеснике у комуникацији:

(31) Додај ми ђу праскуну, а не сливуту. (контрастивно)

(32) Додај ми Ђу праскуву, а не сливуту. (контрастивно)

(33) Додај ми Ђу праскуну, а не сливуву. (контрастивно)

Очигледно је, дакле, да постпозитивни члан нема контрастивну снагу демонстратива у домену читаве синтагме, већ само у уском домену показне заменице, тј. праскуну $\neq$ онуј праску, али праскуну = онуј праску. Из тих разлога се одређени члан не може појавити у контрастираним окружењима када се пресупонира скуп истоврсних референата, али је прихватљив када се контрастира скуп разноврсних ентитета. 


\section{6. Емфатичност}

На крају потпоглавља 5.1 констатовали смо да се емфатички неутрално маркирање дискурс-старих референата релационих именица врши искључиво помоћу постпозитивног члана, а никада анафорским заменицама. Постоје, ипак, ситуације у којима се анафорски употребљеним демонстративом може маркирати старост у дискурсу, али увек уз додатно експресивно читање, које постпозитивни члан не може добити. Погледајмо следећи пример:

(34) А: Леле, измићарката ${ }_{i}$ строшила чашуту!

Б: А, море више, \{овај / тај / онај измићарка $\}_{i} /$ \#измићарката ${ }_{i} \cdot$. (експресивно)

Све тридесеторо консултованих испитаника дели интуицију да се у емфатичким контекстима не може појавити чланована именичка синтагма а да има и додатно, експресивно читање, оцењујући овакву употребу оценом -1 . Ова додатна нијанса у интерпретацији добија се искључиво анафорском заменицом. У овом смислу постоји паралела и са неодређеним детерминаторима један и неки. Тако, у одговарајућем окружењу, индетерминација може бити праћена и експресивном, негативном евалуацијом и/или дистанцом (36)-(37), које нема у одсуству детерминатора (35).

(35) Иван је филозоф.

(36) Иван је један филозоф.

(37) Иван је неки филозоф.

За разлику од стандардне, дискурс-старе анафоре, експресивно читање се у случају тзв. епитета (тј. псеудоанафоре) може добити и чланом и анафорском заменицом:

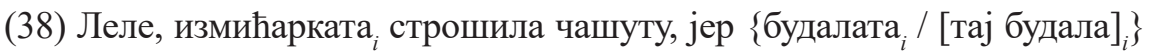
неје видела столицу(ту)!

Коначно, треба приметити да експресивно читање псеудоанафоре произилази не само из употребе демонстратива/анафорика или постпозитивног члана, већ првенствено из евалуативне лексичке семантике самог епитета. Са друге стране, евалуативно неутрални именички референт у примеру (34) (измићарка) добија експресивно читање тек када се употреби анафорска заменица, што, као што смо показали, није случај и са чланованом синтагмом.

\section{7. Резиме}

Ради веће прегледности, у Табели I дати су резултати спроведеног експерименталног истраживања. У одговарајућем пољу наведене су просечне вредности оцена испитаника. Као што можемо приметити, осим асоцијативне анафоре, која може имати и додатну експресивну компоненту приликом 
употребе показне заменице тај (због чега је, супротно нашој претпоставци, оцењена као потпуно прихватљива од стране шест испитаника), резултати недвосмислено потврђују наше полазне хипотезе.

\begin{tabular}{|c|c|c|c|c|}
\hline & $\begin{array}{c}\text { Постпозитивни } \\
\text { члан }\end{array}$ & maj & овај & онај \\
\hline $\begin{array}{c}\text { Старост у дискурсу } \\
\text { релационих именица }\end{array}$ & 1 & -1 & -1 & -1 \\
\hline Јединственост & 1 & -1 & -1 & -1 \\
\hline Генеричност & 1 & -1 & -1 & -1 \\
\hline Асоцијативна анафора & 1 & -0.6 & -1 & -1 \\
\hline Контрастивност & -1 & 1 & 1 & 1 \\
\hline Емфатичност & -1 & 1 & 1 & 1 \\
\hline
\end{tabular}

Табела I. Резултати спроведеног експерименталног истраживања

\section{6. Закључак}

Предмет рада били су физички и језички контексти у којима говорници урбаног пиротског варијетета користе искључиво демонстративе/анафорске заменице, односно, постпозитивне одређене чланове. Након што смо представили кратку историју истраживања члана у балканистици, осврнули смо се на третман ове категорије и демонстратива у домаћој дијалектолошкој литератури. Указали смо на чињеницу да је уобичајена оцена како се демонстративна семантика и даље чува у чланској морфеми, нарочито када су у питању чланови әв и ән. Представили смо потом интуицију и методологију нашег истраживања. Претпоставили смо да ће се члан првенствено појављивати у типовима окружења који подразумевају јединственост номиналног референта, док би демонстратив изворним говорницима био прихватљивији у случајевима када потенцијални денотат чини већи број истоврсних ентитета. Дефинисали смо потом појединачне врсте контекста за које смо хипотетизирали да изискују искључиву употребу једне или друге категорије. Резултати истраживања потврдили су наше претпоставке. Показали смо да je, за разлику од демонстратива/анафорских заменица, постпозитивни одређени члан прагматички прихватљив у дискурс-старом окружењу (и то, само када су у питању релационе именице), у случају јединствености, асоцијативне анафоре и у генеричким контекстима. Са друге стране, указали смо на то да се приликом контрастирања истоврсних ентитета користе само демонстративи, те да је њихова употреба искључива у емфатичким контекстима, када добијају експресивну интерпретацију. 


\section{Цитирана литература}

АСЕНОВА, Петя. Балканско езикознание. Велико Търново: Фабер.

БЕЛИЋ, Александар. Дијалекти источне и јужне Србије. Београд, 1905. Београд: ЗУНС, 1999.

БОГДАНОВИЋ, Недељко. „Говори Бучума и Белог Потока”. Српски дијалектолошки зборник 25. 1979. 1-175.

ВУКАДИНОВИЋ, Вилотије. „Говор Црне Траве и Власине”. Српски дијалектолошки зборник 42. 1996. 1-317.

ВУКОВИЋ, Теодора и Тања САМАРЏИЋ. „Просторна расподела фреквенције постпозитивног члана у тимочком говору”. У: Светлана Ћирковић (ур.). Tuмок. Фолклористичка и лингвистичка теренска истраживања 2015-2017. Књажевац: Народна библиотека „Његош”, Београд: Удружење фолклориста Србије, 2018. 181-199.

ЗЛАТКОВИЋ, Драгољуб. „Пословице и поређења у пиротском говору”. Српски дијалектолошки зборник 34,613-684. 1988.

ИВИЋ, Павле. „О пореклу и особинама пиротског говора (и осталих говора српског југоистока)". Пиротски зборник VIII-IX. Пирот, 1979. Ниш: Просвета, 1991. 191-2014.

КОНЕСКИ, Блаже. Историја на македонскиот јазик. Skopje: Kultura. 1986.

СТАНКОВИЋ, Бранимир. Синтакса и семантика одређеног и неодређеног придевског вида. Докторска дисертација одбрањена на Филолошко-уметничком факултету у Крагујевцу, 2015а.

СТАНКОВИЋ, Бранимир. „Одређени члан у говору Пирота”. Реферат са научног скупа „Александар Белић - 110 година од појаве Српског дијалектолошког зборника", одржаног Филозофском факултету у Нишу, 20156.

СТАНКОВИЋ, Бранимир. „Корелација професије и хиперкорекције код говорника српског језика", Годишњак за српски језик, година XXVII, бр. 14, Ниш: Филозофски факултет, 2016. 227-244.

СТАНКОВИЋ, Станислав. Границе призренско-тимочких говора у власотиначкоме крају. Серија Монографије 5. Институт за српски језик САНУ. Београд: Чигоја штампа. 2008.

СТАНОЈЕВИЋ, Маринко. „Северно-тимочки дијалекат”. Српски дијалектолошки зборник 2. 1911. 360-464.

СТЕВАНОВИЋ, Михаило. Савремени српскохрватски језик 1 (Граматички системи и књижевнојезичка норма). Београд: Научна књига, 1986.

ЋИРИЋ, Љубисав. „Говор Лужнице”. Српски дијалектолошки зборник 29. 1983. 1-190.

ЋИРКОВИЋ, Светлана. 2018. „Увод” у: ЋИРКОВИЋ, Светлана (ур.) Тимок. Фолклористичка и лингвистичка теренска истраживања 2015-2017. Књажевац: Народна библиотека „Његош”, Београд: Удружење фолклориста Србије. 
ФЕКЕТЕ, Егон. „Облик, значење и употреба одређеног и неодређеног придевског вида у српскохрватском језику", 1. део у: Јужнословенски филолог 28/1,2, Београд, 1969, 321-386 и 2. део у: Јужнословенски филолог, 29/3,4, Београд, 1973, 339-523.

APOTHÉLOZ, Denis \& Marie-José Reichler-Béguelin. „Interpretations and functions of demonstrative NPs in indirect anaphora.” Journal of Pragmatics 31, 1999. 363-397.

AUSTIN, John. How to do things with words. Oxford University Press, 1962.

BIRNBAUM, Henrich. "Balkanslavisch und Südslavisch. Zur Reichweite der Balkanismen im südslavischen Sprachraum”. Zeitschrift für Balkanologie III. 1965. 12-65.

BIRNBAUM, Henrich. "Tiefen- und Oberflächstrukturen balkanlinguistischer Erscheinungen”. In (ed. Norbert Reiter) „Ziele und Wege der Balkanlinguistik. Beiträge zur Tagung", 2.-6. März 1981 in Berlin. Wiesbaden: Otto Harrassowitz, 1983. 40-58.

CARLSON, G. and Sussman, R. "Seemingly indefinite definite." In: (ed. S. Kepser, M. Reis) "Linguistic Evidence: Empirical, Theoretical, and Computational Perspectives." Mouton de Gruyter. 2005. 71-86.

CHAFE, Wallace. "Givenness, contrastiveness, definiteness, subjects, topics, and point of view." In (ed. Charles N. Li) "Subject and topic.” New York: Academic Press, 1976. 25-55.

CHRISTOPHERSEN, Paul. The Articles: A Study of Their Theory and Use in English. Copenhagen: Einar Munksgaard. 1939.

CIPARIU, Timotei. 1855. De latinitate linguae valachicae. Blasii. (Schulprogramm)

DIESSEL, Holger. Demonstratives. Amsterdam: John Benjamins. 1999.

FILIPOVIĆ, Jelena. "Language policy and planning in standard language cultures: An alternative approach." In: "Language in Use (Applied Linguistics in Honour of Ranko Bugarski)". Novi Sad: Serbian Association of Applied Linguistics, 2011. 121-136.

FILIPOVIĆ, Jelena \& Jelena Vučo. "Language policy and planning in Serbia: Language management and language leadership". Beograd: Anali Filološkog Fakulteta 24, sv. 2, 2012. 9-32.

GREENBERG, Joseph. "How does a language acquire gender markers". In: (ed. Joseph Greenberg) Universals of human language, vol. 3, Stanford: Stanford University Press. 1978. 47-82.

HALUPKA-REŠETAR, Sabina. Rečenični fokus u engleskom i srpskom jeziku. Novi Sad: Filozofski fakultet, 2011.

HARRIS, Martin. "The marking of definiteness in Romance." In: (ed. J. Fisiak) "Historical Morphology". The Hague: Mouton. 1980. 141-156.

HAWKINS, John. A performance theory of order and constituency. Cambridge: Cambridge University Press. 1994.

HEIM, Irene. The Semantics of Definite and Indefinite Noun Phrases. PhD. Dissertation, University of Massachusetts at Amherst. 1982. Garland Publishing Inc. 1988. 
HEIM, Irene. "File-Change Semantics and the Familiarity Theory of Definiteness." In: (ed. R. Bäuerle et al.) "Meaning, Use and Interpretation of Language", Berlin: de Gruyter, 1983. 164-190.

HINDRICHS, Uwe. Handbuch der Südeuropa-Linguistik. Wiesbaden: Otto Harrassowitz, 1999.

JOSEPH, Brian. The Synchrony and Diachrony of the Balkan Infinitive - A Study in Areal, General and Historical Linguistics. Cambridge: Cambridge University Press. 1983.

KOPITAR, Jernej. "Albanische, walachische und bulgarische Sprache”. Jahrbücher der Literatur, Band 46. Wien, 1829. 59-106.

LEKAKOU, Marika \& Petros Karatsareas. "The two faces of modern Greek determiner spreading." Paper presented at (12 ${ }^{\text {th }}$ ICGL) Workshop on modern Greek dialects, organized at Freie Universität Berlin, 16-19 September 2015.

LYONS, Christopher. Definiteness. Cambridge: Cambridge University Press. 1999.

LÖBNER, Sebastian. "The semantics of nominals". In: (ed. Nick Riemer) "The Routledge Handbook of Semantics.” London, New York: Routledge. 2015.

MARETIĆ, Tomo. Gramatika i stilistika hrvatskoga ili srpskoga književnog jezika. Zagreb, 1899. III izdanje (bez stilistike), Zagreb: Matica hrvatska, 1963.

MIKLOSICH, Franyo. "Die slavischen Elemente im Rumunischen”. Denkschriften der Wiener Akad. Phil.-hist. Cl .Vol. 12, 1861. 1-70.

MIŠESKA TOMIĆ, Olga. Balkan Sprachbund morpho-syntactic features. Dordrecht: Springer, 2006.

POESIO, M. "Weak definites." Proceedings of Semantics and Linguistic Theory (SALT) 4, 1994. 282-299.

REITER, Norbert. Grundzüge der Balkanologie. Ein Schritt in die Eurolinguistik. Wiesbaden: Otto Harrassowitz. 1994.

RUSSELL, Bertrand. “On denoting”. Mind, Volume XIV, Issue 4, 1905. 479-493.

SANDFELD, Kristian. Linguistique balkanique. Problèmes et résultats, Paris, 1930. Paris, 1968.

SCHALLER, Helmut Wilhelm. Die Balkansprachen. Eine Einführung in die Balkanphilologie. Heidelberg. 1975.

SCHROEDER, C. “Articles and article systems in some areas of Europe.” In: (ed. Dahl, Ö., Koptjevskaja-Tamm, M.) “The circum-baltic languages.” Amsterdam: John Benjamins. 2006. 545-615.

SOBOLEV, Andrej. "On the areal distribution of syntactic properties in the languages of the Balkans". In (ed. Olga Tomić) "Balkan Syntax and Semantics.” Amsterdam: John Benjamins, 2004. 59-100.

SOLTA, Georg Renatus. Einführung in die Balkanliguistik mid besonderer Berücksichtigung des Substrats und des Balkanlateinischen. Darmstadt: Wissenschaftliche Buchgesellschaft. 1980.

STANKOVIĆ, Branimir. „DP and mandatory determiners in article-less SerboCroatian", Acta Linguistica Academica Volume 64, Issue 2, Budapest: Akadémiai Kiadó, 2017. 257-279. 
STANKOVIĆ, Branimir \& Marija Stefanović. "Peeling the onion top-down: Language policy in Serbia between power and myth.” Aegean Working Papers in Ethnographic Linguistics 2(1), 2019, 17-41.

SZABÓ, Zoltán Gendler. Descriptions and uniqueness. Philosophical Studies 101, 2000. 29-57.

TRUBETZKOY, Nikolai. "Proposition 16”. In: “Actes du premier congrès international des linguistes" Leiden, 1928. 17-18.

WENKER, Georg. Sprachatlas des Deutschen Reiches. Laut- und Formenatlas. 18881923.

WEINREICH, Uriel. Languages in Contact. The Hague: Mouton. 1953.

WEINREICH, Uriel. "On the compatibility of genetic relationship and convergent development". Word 14, 1958. 374-379.

Branimir Stanković

\section{POSTPOSITIVE DEFINITE ARTICLE AND DEMONSTRATIVE PRONOUNSIN TIMOK-LUŽNICE DIALECT}

The paper investigates the semantic and pragmatic properties of the postpositive definite article and demonstratives in Serbian TimokLužnice dialect. In the literature, there is a consensus on the evaluation that the definite article morpheme functions both as a demonstrative and an article (BELIĆ 1905; STANOJEVIĆ 1911; BOGDANOVIĆ 1979; ĆIRIĆ 1893) and that "the demonstrative nuances still exist in the article" (VUKADINOVIĆ 1996: 203), without a thorough analysis in what conditions the utterance receives a demonstrative or a definite interpretation. We will show that there are contexts in which either the article or the demonstrative is pragmatically acceptable for native speakers. Namely, the results of a conducted research in which the speakers evaluated the pragmatic acceptability of an utterance in a given context on a 3point Likert scale unequivocally show that the definite article is used to mark discourse-old relational nouns' referents, uniqueness, associative anaphora and generic noun phrases, while demonstratives regularly appear with contrastive deictic referential phrases and in emphatic nonepithetic contexts.

Keywords: definite article, demonstratives, TimokLužnice dialect, discourse-old NPs, uniqueness, associative anaphora, generic NPs, contractiveness, emphatic interpretation. 